\title{
Alien shrimps in evidence: new records of the genus Athanas Leach, 1814 on the coast of São Paulo, southern Brazil (Caridea: Alpheidae)
}

\author{
Alexandre O. Almeida • Sabrina M. Simões • \\ Rogério C. Costa $\cdot$ Fernando L. Mantelatto
}

Received: 4 September 2011/Revised: 22 November 2011/ Accepted: 7 January 2012/Published online: 18 January 2012

(C) Springer-Verlag and AWI 2012

\begin{abstract}
The occurrence of two alien alpheid shrimps of the genus Athanas Leach, 1814 [in Leach 1813-1814], the Indo-West Pacific A. dimorphus Ortmann, 1894 and the Eastern Atlantic A. nitescens (Leach, 1813 [in Leach 18131814]), on the coast of the state of São Paulo, Brazil, is reported. The presence of $A$. dimorphus extends the range
\end{abstract}

Communicated by Heinz-Dieter Franke.

A. O. Almeida $(\bowtie)$

Departamento de Ciências Biológicas,

Universidade Estadual de Santa Cruz,

Rodovia Ilhéus-Itabuna, km 16, Ilhéus,

BA 45662-900, Brazil

e-mail: aalmeida@uesc.br

S. M. Simões · R. C. Costa

Programa de Pós-Graduação em Ciências Biológicas,

A/C: Zoologia, Instituto de Biociências,

Universidade Estadual Paulista,

Distrito Rubião Jr., s/no, Botucatu,

SP 18618-970, Brazil

e-mail: smsimoes@ibb.unesp.br

R. C. Costa

e-mail: rccosta@fc.unesp.br

S. M. Simões · R. C. Costa

Departamento de Ciências Biológicas. LABCAM (Laboratório

de Biologia de Camarões Marinhos e de Água Doce),

Universidade Estadual Paulista, Av. Eng. Luiz Edmundo Carrijo

Coube, 14-01, Bauru, SP 17033-360, Brazil

F. L. Mantelatto

Laboratório de Bioecologia e Sistemática de Crustáceos (LBSC),

Programa de Pós-Graduação em Biologia Comparada,

Departamento de Biologia, Faculdade de Filosofia,

Ciências e Letras de Ribeirão Preto (FFCLRP),

Universidade de São Paulo (USP), Av. Bandeirantes 3900,

Ribeirão Preto, SP 14040-901, Brazil

e-mail: flmantel@usp.br of this species in the western Atlantic farther to the south in Brazil, whereas A. nitescens is reported for the first time in the western Atlantic, representing the second alien alpheid species on this side of the Atlantic and the twenty-first decapod crustacean introduced in Brazil. We provide morphological accounts of the material examined and illustrate the most important diagnostic characters of both species. An overview of the possible mechanisms of their introduction on the coast of São Paulo is also provided.

Keywords Crustacea - Decapoda $\cdot$ Athanas .

Exotic species - Western Atlantic

\section{Introduction}

The alpheid shrimp genus Athanas Leach, 1814 [in Leach 1813-1814] is currently represented by 38 recognized species, distributed in the Indo-West Pacific and in the eastern Atlantic (from Norway to Angola, including the entire Mediterranean) (Anker and Jeng 2007; Anker and Ahyong 2007; Anker et al. 2010; Anker and Komai 2010; Anker 2011). Similarly to many other decapods, they are naturally absent from the western Atlantic. The first alien species of Athanas (A. dimorphus Ortmann, 1894) was only recently reported from the state of Ceará, Brazil (Pachelle et al. 2011). These shrimp are small and inconspicuous, less than $10 \mathrm{~mm}$ in total length, and have cryptic habits, being found in crevices of coral and rubble, under rocks, or living commensally in burrows of larger crustaceans such as stomatopods and upogebiids or on echinoderms (Anker et al. 2010; Anker and Komai 2010).

The genus Athanas was classified by Coutière (1899) into two informal species groups. In the species assigned to the A. nitescens (Leach, 1813 [in Leach 1813-1814]) 
group, the more homogeneous (Anker and Jeng 2007), the chelipeds are carried extended, whereas in the more speciose and heterogeneous second group, the A. dimorphus group, the chelipeds are carried folded. The latter may be further subdivided into several smaller groups based on cheliped morphology, frontal margin configuration, and walking legs (Anker and Jeng 2007).

During the course of our long-term investigation on the biology and taxonomy of decapod crustaceans from the São Paulo coast region, two of the authors (RCC and FLM) captured individuals of a species not previously obtained during our surveys. Three specimens collected on rocks at Lamberto Beach, Ubatuba, southern coast of São Paulo, were readily recognized as Athanas specimens based on their partially exposed eyes, long rostrum, chelipeds with no snapping mechanism, and presence of an articulated plate on the sixth abdominal segment near the protopod of the uropods. Further analysis showed that these specimens match the diagnostic characters of the Indo-West Pacific A. dimorphus (see Banner and Banner 1973; Chace 1988), recently reported from northeastern Brazil (Pachelle et al. 2011).

During a community-structure study on the marine shrimps carried out in the São Vicente estuary, a region about $200 \mathrm{~km}$ farther south on the São Paulo coast, a male specimen of Athanas was caught with an otter trawl net (mesh size 20 and $18 \mathrm{~mm}$ in the cod end). The morphological characters of this specimen matched those of the eastern Atlantic A. nitescens (see Holthuis 1951; Holthuis and Gottlieb 1958).

This contribution provides a range extension of $A$. dimorphus in Brazil and reports the first occurrence of A. nitescens in the western Atlantic. Because both species could represent species complexes (Anker 2001; Anker and Ahyong 2007), we provide morphological accounts of the material examined and illustrations of the most important diagnostic characters of both species in order to aid future identification in different areas. Additionally, inferences on mechanisms of introduction to the coast of São Paulo are discussed.

\section{Materials and methods}

The material of Athanas studied here is deposited in the Crustacean Collection of the Department of Biology, Faculty of Philosophy, Science and Letters of Ribeirão Preto (FFCLRP), University of São Paulo, Brazil (CCDB/ FFCLRP/USP). Comparative material of A. nitescens, deposited in the Crustacea Collection of the Museum of Zoology, University of São Paulo, São Paulo, Brazil (MZUSP), was also examined. Drawings were made under a dissecting microscope equipped with a drawing tube.
Carapace length (CL) was measured from the tip of the rostrum to the posterior margin of the carapace, under a drawing tube. Morphological data and diagnoses for both species were gathered by reviewing the descriptions in the references mentioned in the Introduction and Results. A search was made for diagnostic morphological differences to support our findings. Following Anker and Ahyong (2007), the term "spiniform seta" is used for robust articulated cuticular extensions usually referred as "spine" or "movable spine" in the literature. Other abbreviations used: (f) non-ovigerous female; (m) male; (ovf) ovigerous female.

\section{Results}

Taxonomy

Family Alpheidae Rafinesque, 1815

Genus Athanas Leach, 1814 [in Leach 1813-1814]

Athanas dimorphus Ortmann, 1894

(Fig. 1)

Description Athanas dimorphus Ortmann, 1894: 12, pl. 1, Fig. 1. See Anker and Jeng (2007) for a list of synonyms.

Material examined $1 \mathrm{~m}$ (CL $5.1 \mathrm{~mm}), 1 \mathrm{f}$ (CL $3.6 \mathrm{~mm}), 1$ ovf (CL $4.3 \mathrm{~mm}$ ), Brazil, São Paulo, Ubatuba, Lamberto Beach $\left(23^{\circ} 30^{\prime} 0.12^{\prime \prime} \mathrm{S} ; 45^{\circ} 07^{\prime} 5.60^{\prime \prime} \mathrm{W}\right)$, colls. F.L. Mantelatto et al., on rocks, 3.V.2007 (CCDB 1945).

Type locality Dar-es-Salaam, Tanzania, Upanga Reef.

Distribution Indo-West Pacific-East Africa, Red Sea, Thailand, Hong Kong, Philippines, Japan, Australia (Western Australia, Northern Territory, and Eastern Australia), and New Caledonia (Banner and Banner 1973; Chace 1988). Western Atlantic-Brazil, states of Ceará (Pachelle et al. 2011) and São Paulo (present study).

Ecology In the Indo-West Pacific on shallow reef flats and intertidal rocky and mixed sand-rock or mud-rock flats; in tide pools, under coral rubble and rocks and coral heads at low tide, and from broken coral; intertidal to $100 \mathrm{~m}$, more commonly between 0 and $3 \mathrm{~m}$ (Banner and Banner 1973; Pachelle et al. 2011). In Ceará, Brazil, specimens were collected under rocks and in tidal pools (Pachelle et al. 2011). At Ubatuba (present study), the specimens were found on rocks during low tide.

Morphological account Rostrum length variable, reaching slightly beyond 1/2 length of second segment of antennular peduncle (male) (Fig. 1a), around 1/2 length of third segment and almost to the distal end of second segment of antennular peduncle in females. Pterygostomial angle acute (male) (Fig. 1b) or rounded (females). 


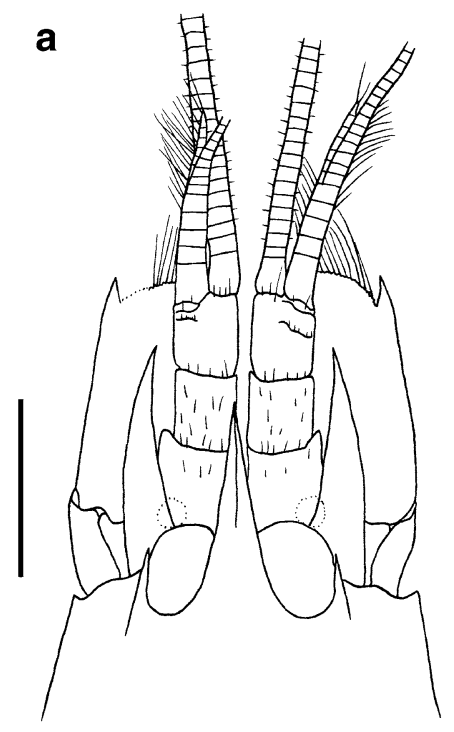

b

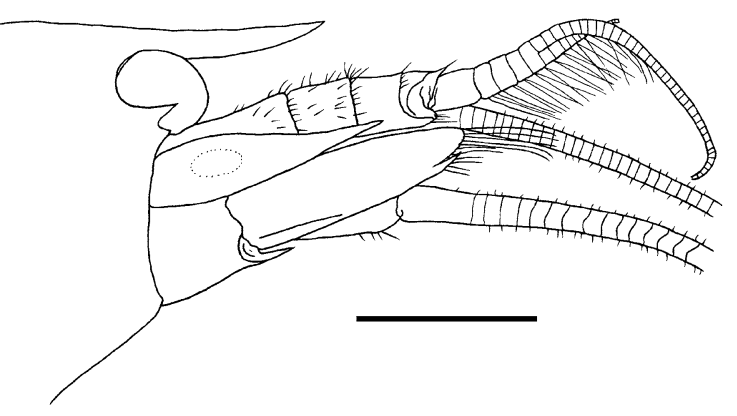

c
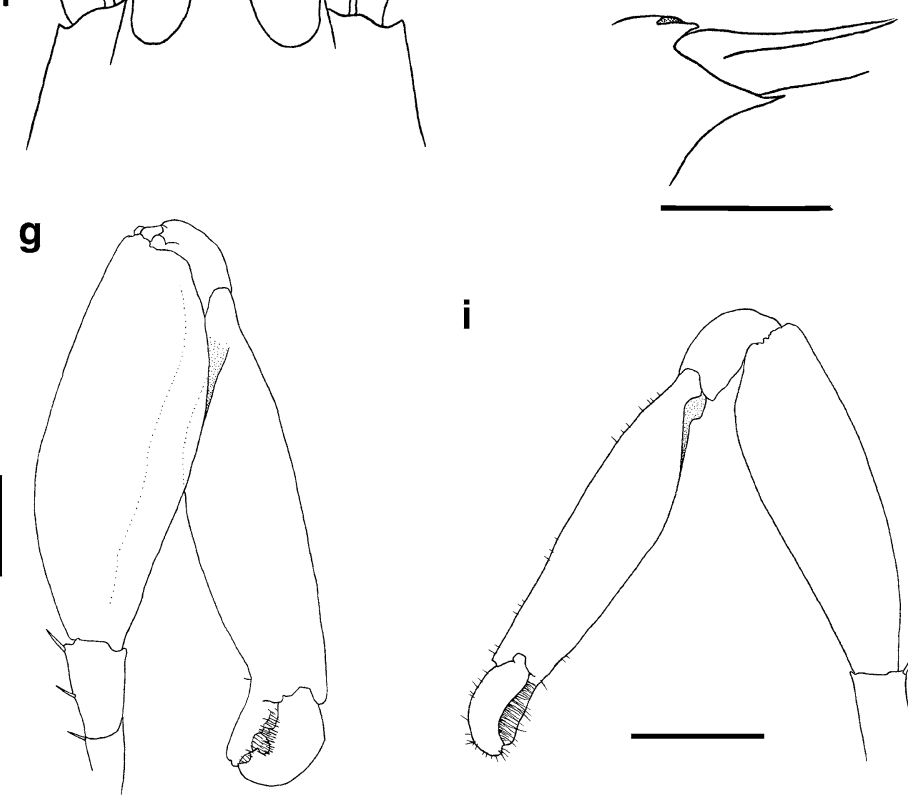

i

$\mathbf{k}$

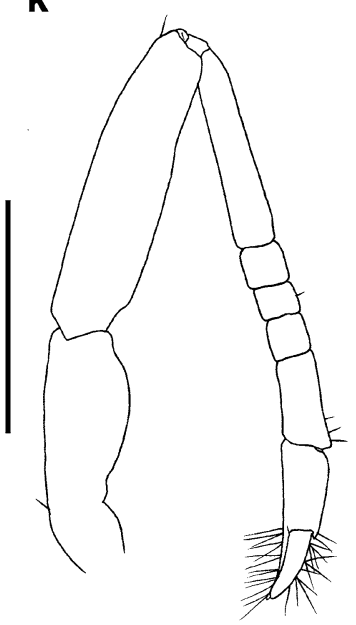

j

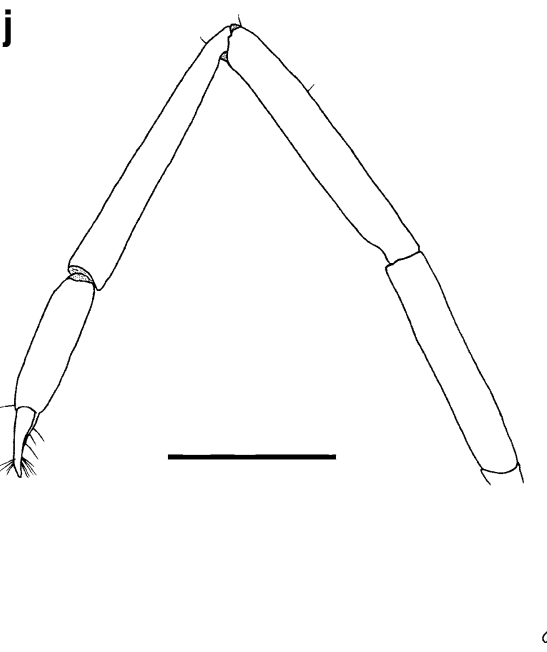

e

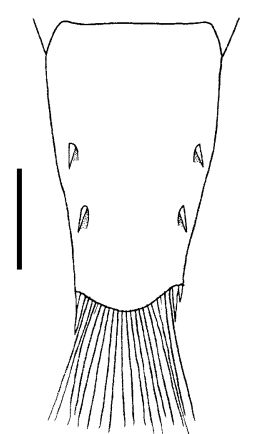

d

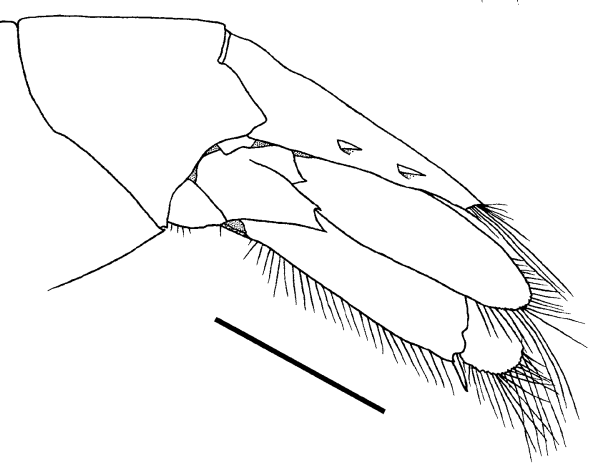

h

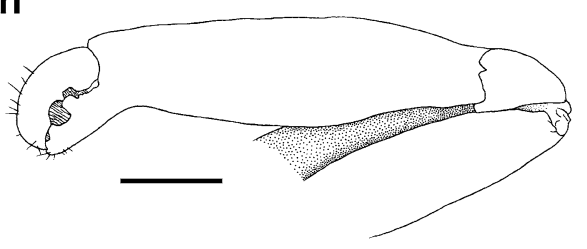

f

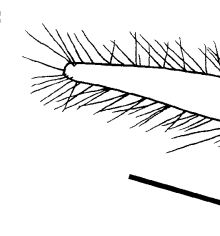

Fig. 1 Athanas dimorphus Ortmann, 1894, male (a-i, k, l) and female (j) from Lamberto Beach, Ubatuba, São Paulo, Brazil (CCDB 1945). a Head and cephalic appendages, dorsal view; b head and cephalic appendages, lateral view; c right basicerite, view of infero-lateral portion; $\mathbf{d}$ sixth abdominal segment, uropods, and telson, lateral view; e telson, dorsal view; f left third maxilliped, ventral view; $\mathbf{g}$ right major cheliped, lateral view; $\mathbf{h}$ detail of right major cheliped, mesial view; i left minor cheliped, lateral view; $\mathbf{j}$ left female cheliped, lateral view; $\mathbf{k}$ right pereiopod 2, lateral view; $\mathbf{l}$ right pereiopod 3, lateral view. Scale bars $=\mathbf{a}, \mathbf{b}, \mathbf{d}, \mathbf{g}-\mathbf{l}=1 \mathrm{~mm} ; \mathbf{c}, \mathbf{e}, \mathbf{f}=0.5 \mathrm{~mm}$ 
Supra-corneal tooth absent; extra-corneal tooth acute, well developed; infra-corneal tooth shorter than extra-corneal tooth, with tip rounded (Fig. 1b). Stylocerite reaches (ovigerous female) or almost reaches (other specimens) 1/2 length of third segment of antennular peduncle (Fig. 1a, b). Blade of scaphocerite reaches (ovigerous female) or overreaches (other specimens) distal end of antennular peduncle (Fig. 1a, b); blade as long as distolateral tooth (ovigerous female) or overreaching it (other specimens) (Fig. 1a). In lateral view, carpocerite reaches approximately $1 / 2$ length of third segment of antennular peduncle (Fig. 1b). Basicerite armed with two teeth: dorsal tooth triangular and infero-lateral tooth tapering to an acute apex (Fig. 1c). Exopodite of maxilliped 3 almost reaches distal end of antepenultimate segment of endopodite (Fig. 1f).

First chelipeds unequal in male; right more robust than left (Fig. 1g-i); ischium of both chelipeds armed with two long spiniform setae (Fig. 1g); merus of right chela laterally compressed, non-toothed, conspicuously wider than palm, but similar in length (Fig. 1g); ventral portion strongly excavated to accommodate the chelae when folded (Fig. 1h); carpus short (approximately 0.25 merus and palm length) (Fig. 1g, h); palm compressed laterally, diameter variable; proximal portion considerably narrower than middle (widest portion) and distal portions (Fig. 1h); fingers distinctly less than $1 / 2$ palm length (Fig. 1g, h); dactylus strongly arched, pollex almost straight; cutting edge of fingers fringed with setae, armed with irregular dentition (Fig. 1g, h); dactylus armed with three teeth, the middle one squared; pollex armed with two large teeth, proximal strongly squared, located at median point, and distal placed near pollex tip and more rounded. Left chela similar in shape (Fig. 1i). Its smaller size may result from an earlier loss and regeneration process. Chelipeds in females much weaker than those of males, chelae shorter than merus (Fig. 1j), matching the differences recorded by Banner and Banner (1973, p. 314, Fig. 6g-k). Ischium without dorsal spiniform setae, as those of the males.

Pereiopod 2 with merus and ischium broader in males than in females; carpus segment ratio (proximal to distal) 5:1:1:1:2 (Fig. 1k); dactylus of P3-P5 simple; strong spiniform seta on flexor distal margin of propodus, especially on P4 and P5 (Fig. 11); ischium of P3-P4 armed with spiniform setae only in the male and non-ovigerous females (Fig. 11); ischium of P5 armed only in non-ovigerous females (both P5 detached in male).

Appendix interna of male reaches approximately $1 / 2$ length of appendix masculina. Posterolateral margin of fifth abdominal segment acute in males, rounded in females (Fig. 1d). Sixth abdominal segment with conspicuous movable plate, typical of Athanas (Fig. 1d). Uropods have bifid protopods, each lobe ending in acute tooth (Fig. 1d).
Distolateral spiniform seta slender, reaching posterior margin of exopod. Telson about twice as long as wide at base (Fig. 1e). Dorsal spiniform setae of telson in male and ovigerous female located close to lateral margins; first and second pairs placed at $1 / 3$ and $2 / 3$ length of telson (Fig. 1e). In non-ovigerous female, first pair of dorsal setae placed around mid-length of telson. Posterior margin of the telson broadly convex, with two pairs of weak spiniform setae and long setae on tip (Fig. 1e).

Remarks In the São Paulo material, the rostrum length, the shape of the pterygostomial angle (acute or rounded), and the presence/absence of spiniform setae on the ischium of P3-P5 were the most variable characters. In A. dimorphus, the rostrum usually overreaches the second antennular peduncle (Banner and Banner 1973; Chace 1988; Pachelle et al. 2011). Athanas dimorphus may represent a species complex, and the taxonomic status of some of its synonyms such as A. setoensis Kubo, 1951 and A. dimorphus seedang Banner \& Banner, 1966 needs further investigation (Anker and Ahyong 2007; Anker and Jeng 2007). Athanas dimorphus can be differentiated from all other eastern Atlantic Athanas by the shape of the chelipeds, especially the inflated merus (Pachelle et al. 2011).

Athanas nitescens (Leach, 1813 [in Leach 1813-1814]) (Fig. 2)

Description Palaemon nitescens Leach, 1813 [in Leach 1813-1814]: 401. See Anker and Jeng (2007) for a list of the principal synonyms.

Material examined $1 \mathrm{~m}$ (CL $5.1 \mathrm{~mm})$, Brazil, São Paulo, São Vicente estuary, Station $1 \quad\left(23^{\circ} 57^{\prime} 7.28^{\prime \prime} \mathrm{S}\right.$; $\left.46^{\circ} 25^{\prime} 15.98^{\prime \prime} \mathrm{W}\right)$, trawl, $3.9 \mathrm{~m}$ depth, salinity $25.5 \pm 1.93$ PSU, temperature $25.4 \pm 2.5^{\circ} \mathrm{C}$, coll. S.M. Simões and R.C. Costa, 16.VI.2009 (CCDB 3480).

Comparative material $1 \mathrm{~m}, 2 \mathrm{f}$, France, Gulf of St. Malô, Îles Chausey, littoral, coll. K. Baba et al., 26-31.VIII.1996 (MZUSP 21952).

Type locality Southern coast of Devonshire, England.

Distribution Eastern Atlantic-southwestern Norway to Republic of the Congo, including the Mediterranean (Holthuis and Gottlieb 1958; Crosnier 1971; d'Udekem d'Acoz 1999). Western Atlantic-Brazil, state of São Paulo (present study).

Ecology On hard substrata such as coral, calcareous algae, under rocks, on hulls of boats, artificial reefs (cement blocks), rarely on marl, sedimentary bottoms, seagrass meadows (Posidonia oceanica), sea anemone Telmatactis cricoides (Duchassaing, 1850), in shells inhabited by the hermit crab Dardanus calidus (Risso, 1827), on exotic oysters in the 


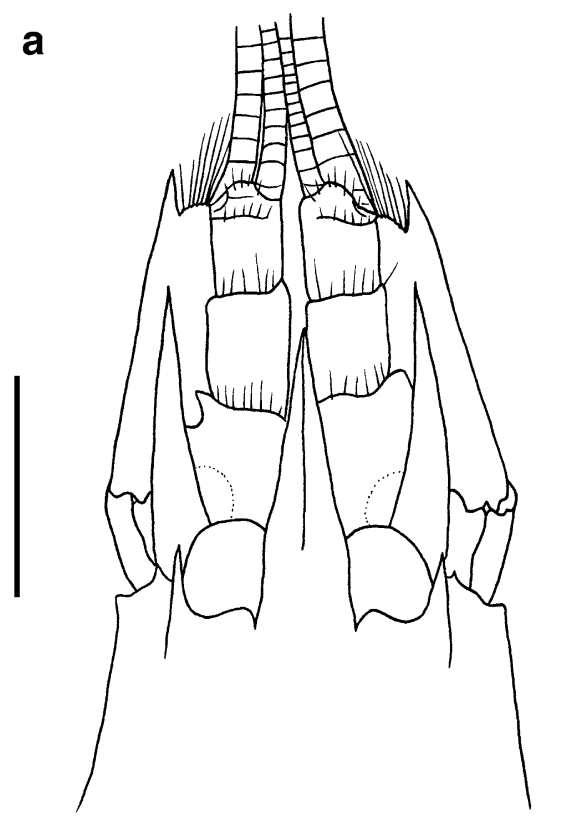

b

e
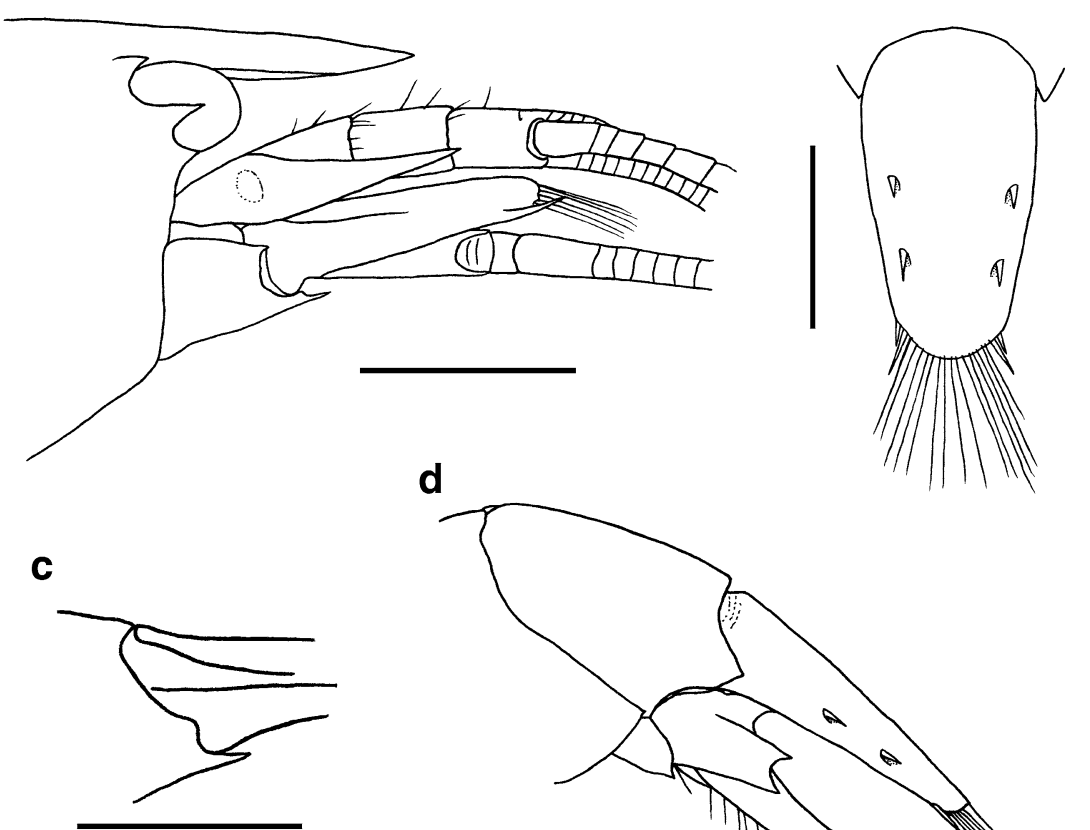

d
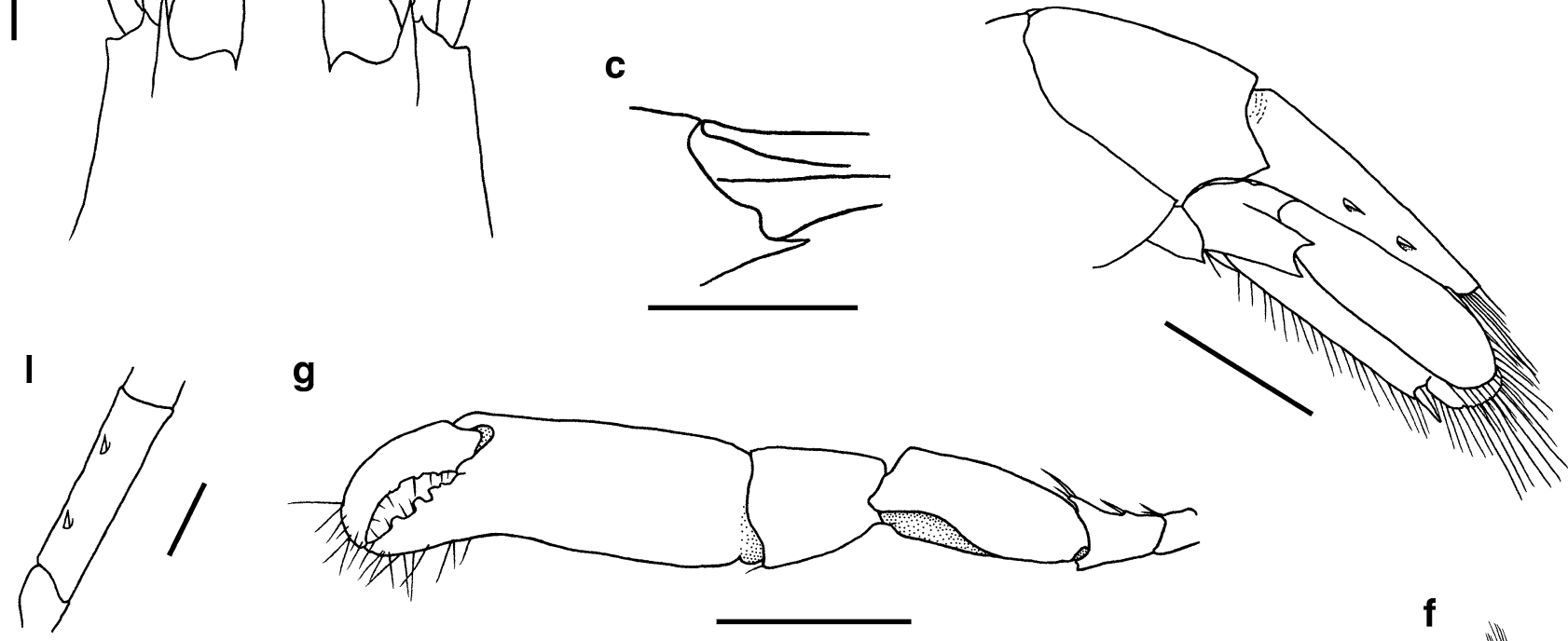

g

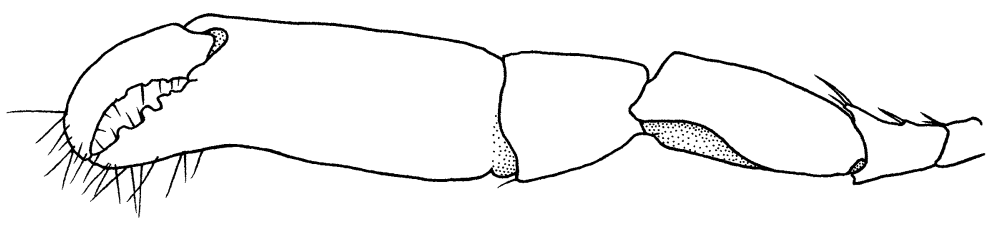

f
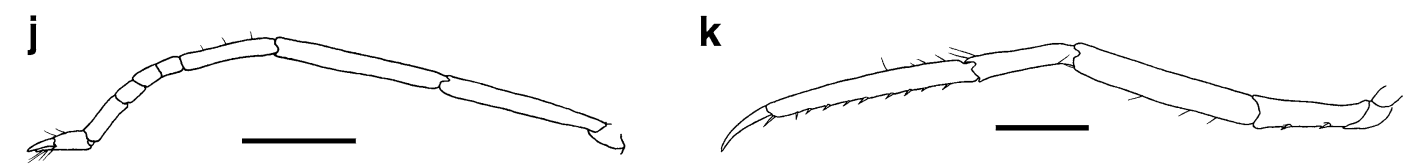

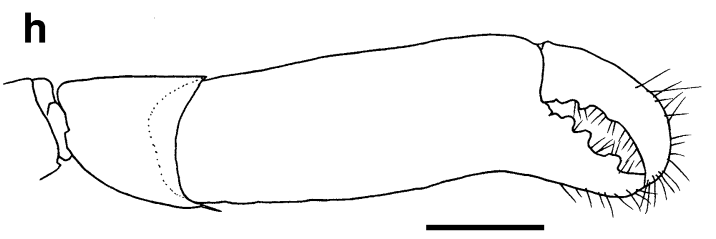

Fig. 2 Athanas nitescens (Leach, 1813 [in Leach 1813-1814]), male from São Vicente estuary, São Vicente, São Paulo, Brazil (CCDB 3480). a Head and cephalic appendages, dorsal view; b head and cephalic appendages, lateral view; c right basicerite, infero-lateral view; d sixth abdominal segment, uropods, and telson, lateral view;

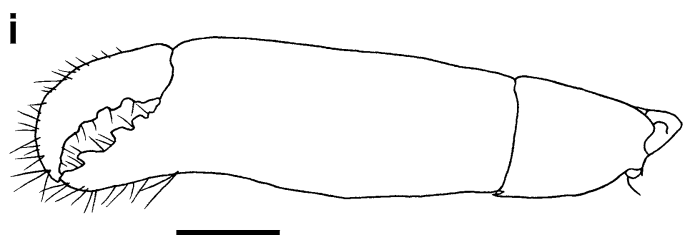

e telson, dorsal view; f left third maxilliped, ventral view; g left cheliped, lateral view; $\mathbf{h}$ left cheliped, mesial view; i right cheliped, mesial view; $\mathbf{j}$ right pereiopod 2, lateral view; $\mathbf{k}$ right pereiopod 3, lateral view; $\mathbf{I}$ ischium of pereiopod 3, lateral view. Scale bars $=\mathbf{g}=2 \mathrm{~mm} ; \mathbf{a}, \mathbf{b}, \mathbf{d}-\mathbf{f}, \mathbf{h}-\mathbf{k}=1 \mathrm{~mm} ; \mathbf{c}, \mathbf{l}=0.5 \mathrm{~mm}$
Mediterranean [Pinctada radiata (Leach, 1814)]; intertidal to 65 m (Ledoyer 1968; Crosnier 1971; Wirtz 1997; d'Udekem d'Acoz 1999; d'Udekem d'Acoz and Wirtz 2002; Manoudis et al. 2005; Ateş et al. 2006; Tlig-Zouari et al. 2011).
Morphological account Rostrum slightly overreaches $1 / 2$ length of second segment of antennular peduncle (Fig. 2a, b). Pterygostomial angle rounded (Fig. 2b). Apex of supra-corneal tooth rounded; a broad and sharp notch 
lies between it and the lateral margin of rostrum (Fig. 2a). Extra- and infra-corneal teeth well developed, tapering to acute tip (Fig. 2b). Infra-corneal narrower than extra-corneal, almost reaching the same level as the latter (Fig. 2b). Stylocerite slightly overreaches distal limit of second segment of antennular peduncle (Fig. 2a, b). Blade of scaphocerite reaches distal end of third segment of antennular peduncle (Fig. 2a). On the left side, distolateral tooth slightly overreaches distal limit of blade, whereas on the right side, they end at same level (Fig. 2a). In lateral view, carpocerite reaches approximately $1 / 2$ length of third segment of antennular peduncle (Fig. 2b). Basicerite armed with two teeth, the dorsal tooth with rounded tip and tooth on the infero-lateral portion, acute (Fig. 2c). Rounded lobe lies between these teeth (Fig. 2c). Antepenultimate segment of endopodite of maxilliped 3 narrower than in A. dimorphus; exopodite overreaches distal end of antepenultimate segment (Fig. 2f).

First chelipeds subequal (Figs. 2h, i). Dorsal margin of ischium armed with long stout spiniform setae, placed on the top of elevations (Fig. 2g). Distal elevation bears two setae, near joint with carpus (Fig. 2g). Merus short and narrow (around 0.8 times palm length), non-toothed, slightly flattened laterally, and slightly excavated on distal portion of ventral margin (Fig. 2g). Carpus cup-shaped and around 0.6 times merus length and slightly less than half palm length (Fig. $2 \mathrm{~g}-\mathrm{i}$ ). Distal portion of carpus as wide as palm (Fig. 2g-i). Palm inflated, subcylindrical on proximal portion, and laterally compressed on distal portion (Fig. $2 \mathrm{~g}-\mathrm{i}$ ). Dorsal and ventral margins almost parallel (Fig. $2 \mathrm{~g}-\mathrm{i}$ ). Fingers correspond to around $1 / 2$ length of palm (Fig. 2g-i). Dactylus strongly arched and pollex almost straight (Fig. 2g-i). Cutting edge fringed with setae and armed with teeth of variable size (4 on dactylus and 5 on pollex) (Fig. 2g-i).

Other pereiopods somewhat more slender than in $\mathrm{A}$. dimorphus. Segment ratio (proximal to distal) of carpus of P2 4:1:1:1:2 (Fig. 2j); dactylus of P3-P5 simple (Fig. 2k). Spiniform seta on flexor distal margin of propodus on $\mathrm{P} 4$ and P5 not strong as in A. dimorphus (Fig. 2k). Ischium of P3-P5 armed with 2, 2 and 1 strong spiniform setae, respectively.

Appendix interna reaches approximately $1 / 2$ length of appendix masculina. Posterolateral margin of fifth abdominal segment ends in a right angle (Fig. 2d). Sixth abdominal segment provided with a typical Athanas movable plate (Fig. 2d). Uropods have bifid protopods, each lobe ending in acute tooth (Fig. 2d). Distolateral spiniform setae somewhat more robust than in A. dimorphus, almost reaching posterior margin of exopod. Telson about twice as long as wide at base (Fig. 2e). Dorsal spiniform setae of telson located close to lateral margins; first pair placed at mid-length of telson; second pair placed midway between first pair and posterior margin of telson (Fig. 2e). Posterior margin of telson broadly convex, with two pairs of spiniform setae (more robust than in $A$. dimorphus) and long setae on the tip (Fig. 2e).

Remarks Athanas nitescens may also represent a species complex (Anker 2001; Anker and Ahyong 2007). Holthuis (1951) considered that two morphologically close species, A. nitescens and A. laevirhinchus Risso, 1816, exist in the eastern Atlantic and the Mediterranean. Later, Holthuis and Gottlieb (1958), after analyzing a larger sample of A. nitescens, concluded that this group was represented by two forms in the Mediterranean, the typical A. nitescens, and a slender form named by them A. nitescens var. laevirhinchus (Risso, 1816). However, those forms could not be regarded as distinct species or subspecies, since intermediate individuals existed and both forms were often found at the same localities. Undoubtedly, our specimen matches the typical characters of A. nitescens, characterized by the rostrum straight and high, the extra-corneal tooth stronger and more acute than the infra-corneal, the less-pronounced angle of the pleura of the fifth abdominal segment, the broader antennular peduncle, the scaphocerite twice as long as broad with outer margin straight, and distolateral tooth slightly overreaching the blade (see Fig. 2a, b), among others (see Holthuis and Gottlieb 1958, p. 28, Fig. 2). The specimens from Îles Chausey, France, deposited at MZUSP, although in poor condition, agree in general with the specimen from Brazil. However, the rostrum, in lateral view, is narrower and curved slightly upwards. The infra-corneal tooth is well developed and reaches beyond the tip of the extra-corneal tooth. The posterolateral margin of the fifth abdominal segment is more pronounced. These are characters described for A. nitescens var. laevirhinchus (Holthuis and Gottlieb 1958). On the other hand, their broad antennular peduncle, the carpus of the female chelipeds much shorter than the palm, and the robust fused part of the two branches of the outer antennular flagellum are characters of the typical form. The stylocerite width varied. Athanas laevirhinchus was considered a synonym of $A$. nitescens by Anker and Jeng (2007), and according to them, the statuses of this species and of another synonym, A. veloculus Spence Bate, 1888, need confirmation. Athanas nitescens is similar to two other eastern Atlantic species, A. nouvelae Holthuis, 1951 and A. grimaldii Coutière, 1911. The former differs from A. nitescens by the rostrum being more slender and curved distinctly upward (vs. higher and forward-directed or curved slightly upward in A. nitescens), the shorter stylocerite, and the presence of an accessory tooth on the flexor margin of the P3-P5 dactylus. The latter differs from A. nitescens mainly by the shorter rostrum, by the close proximity of the 
extra and infra-corneal teeth, by the longer appendix masculina (overreaching the tip of the endopod), and by the flexor margin of the P3-P5 dactylus being minutely biunguiculate (see Holthuis 1951).

\section{Discussion}

The presence of two species of Athanas on the Brazilian coast represents a new insight into the genus occurrence, with a second alien alpheid species present in the western Atlantic. Details about the morphology and biology of these species are provided below.

The chelae are carried folded in A. dimorphus and extended in $A$. nitescens. For this reason, in males of A. dimorphus, the merus is inflated, laterally flattened, and wider than the palm, and its ventral portion is strongly excavated to accommodate the chelae when folded (Fig. 1g, h). In contrast, in males of A. nitescens, the merus is short and narrow, slightly flattened laterally, and slightly excavated on the distal ventral margin (Fig. 2g). These features easily distinguish these species. For additional characters that may be useful to separate A. dimorphus and A. nitescens, refer to Table 1 .

Lists of alien decapod crustaceans known from Brazil have been published recently (Tavares and Mendonça Jr 2004; Pachelle et al. 2011; Tavares 2011). With the addition of A. nitescens reported here, the number of nonindigenous decapods that have been reported in marine, brackish, and fresh waters of Brazil rises to 21.

Alpheids generally are not widely reported as alien species, in comparison to some other decapod groups.
Some alpheids in the Mediterranean are Lessepsian migrants from the Red Sea (Galil 1992; d'Udekem d'Acoz 1999; Galil et al. 2002), but transoceanic dispersal suggests modes of introduction such as ballast water or associated with biofouling on ship hulls, two of the most important vectors of introduction (Rodríguez and Suárez 2001; Gollasch 2002; Tavares 2003; Tavares and Mendonça Jr 2004). The cryptic lifestyle of alpheids may in the first instance prevent removal from the source population and secondly prevent detection once in the new area. Moreover, alpheids are generally difficult to identify and include a number of species complexes. Thus, it is possible that they are simply being misidentified elsewhere.

The collection sites of $A$. dimorphus in Ceará are located near shipping and oil terminals, including the Mucuripe harbor area. The possible means of introduction of this species into northeastern Brazil were discussed by Pachelle et al. (2011). The morphology of its first zoeal stages suggests an extended planktonic development, allowing its larvae to survive for months in ballast water of large ships. In contrast, because of their small size, the adults could have been transported in hull fissures or among hull biofouling (Pachelle et al. 2011). Several Indo-West Pacific decapods are believed to have been introduced into the western Atlantic by means of ballast water: Charybdis hellerii (A. Milne-Edwards, 1867), Metapenaeus monocerus (Fabricius, 1798), Penaeus monodon (Fabricius, 1798), and Scylla serrata (Forskal, 1775) (Mantelatto and Dias 1999; Tavares and Mendonça Jr 2004). The first two are believed to have been introduced in ballast water taken in an eastern Mediterranean harbor and discharged in western Atlantic harbors. Penaeus monodon has been cultivated in

Table 1 Characters useful for distinguishing the shrimps Athanas dimorphus Ortmann, 1894 and A. nitescens (Leach, 1813 [in Leach 1813-1814])

\begin{tabular}{|c|c|c|}
\hline Species characters & Athanas dimorphus & Athanas nitescens \\
\hline Chelae pattern & Carried folded & Carried extended \\
\hline Merus of male chela & $\begin{array}{l}\text { Inflated, laterally flattened, and wider than palm; } \\
\text { ventral portion strongly excavated to accommodate } \\
\text { chelae when folded }\end{array}$ & $\begin{array}{l}\text { Short and narrow, slightly flattened laterally, and slightly } \\
\text { excavated on distal ventral margin }\end{array}$ \\
\hline Carpus of male chela & $\begin{array}{l}\text { Very short, corresponding to only } 0.25 \text { times palm } \\
\text { length }\end{array}$ & $\begin{array}{l}\text { Cup-shaped, slightly less than half palm length; distal } \\
\text { portion as wide as palm }\end{array}$ \\
\hline Palm of male chela & $\begin{array}{l}\text { Distinctly narrower and more inflated in middle and } \\
\text { distal portions; wider in middle portion }\end{array}$ & $\begin{array}{l}\text { Inflated, subcylindrical in proximal portion, and laterally } \\
\text { compressed in distal portion; dorsal and ventral margins } \\
\text { almost parallel }\end{array}$ \\
\hline Fingers of male chela & Distinctly less than $1 / 2$ palm length & Roughly $1 / 2$ length of palm \\
\hline Supra-corneal tooth & Absent & Present, with rounded tip \\
\hline Infra-corneal tooth & Rounded tip; fails to reach apex of extra-corneal tooth & Acute tip; almost reaches tip of extra-corneal tooth \\
\hline Basicerite & No rounded lobe; acute infero-lateral tooth present & With a rounded lobe and an acute infero-lateral tooth \\
\hline Merus of male P2 & Broad (approximately 4 times as long as broad) & Narrow (approximately 9 times as long as broad) \\
\hline $\begin{array}{l}\text { Antepenultimate } \\
\text { segment of endopodite } \\
\text { of maxilliped } 3\end{array}$ & Broad & Narrow \\
\hline
\end{tabular}


the Mediterranean, and it is possible that the mode of introduction is identical to that of the first two species. Of these, only $C$. hellerii is considered well established in Brazil, based on its reproductive and population performance (Mantelatto and Garcia 2001; Tavares 2011). Of the five species mentioned above, only $A$. dimorphus might have been transported transoceanically on ship hulls. Discovery of the true mechanism of introduction of $A$. dimorphus is a difficult task, because Brazil has neither facilities aiming for early detection of exotic species nor a long-term monitoring program of marine invasions (Fernandes et al. 2009). Collection of alien species is often a by-product of ecological and survey studies performed by Brazilian researchers (Tavares 2011), as well as residents of different regions. The present records were made as part of a long-term project on the taxonomy of decapod crustaceans along the São Paulo coast.

The recent collections of $A$. dimorphus at mutually distant sites such as Ceará and São Paulo possibly involve its introduction at one or more sites, as suggested for C. hellerii (Campos and Türkay 1989; Gómez and Martínez-Iglesias 1990; Lemaitre 1995; Tavares and Mendonça Jr 1996; Mantelatto and Dias 1999). The collection of ovigerous females in both Ceará and São Paulo suggests that $A$. dimorphus is established in these two states. After a successful introduction, colonization of new areas via larval or adult dispersion, or transportation by intracoastal traffic, is expected, as suggested for $C$. hellerii (Tavares and Mendonça Jr 1996; Mantelatto and Garcia 2001; Tavares and Amouroux 2003).

Introduction by means of ship ballast water and biofouling may also be responsible for the introduction of A. nitescens. According to Bartilotti et al. (2005), it is reasonable to assume that $A$. nitescens could pass through eight zoeal stages until metamorphosis to megalopa. Alpheid shrimps with more than four zoeal stages are considered extended-development species, and their larval development could last several weeks (Knowlton 1973). Thus, it is possible that $A$. nitescens larvae present in water taken as ship ballast in the eastern Atlantic and the Mediterranean could survive a transoceanic cruise to Brazil. On the other hand, its presence on a wide variety of substrata, especially on hard bottoms as noted above (see d'Udekem d'Acoz and Wirtz 2002; Manoudis et al. 2005; Tlig-Zouari et al. 2011, for example), makes it plausible that it was introduced as a biofouling organism on ship hulls or other hard substrata. The eastern Atlantic brachyurans Polybius navigator (Herbst, 1794), Acidops cessacii (A. MilneEdwards, 1878), and Cancer pagurus (Linnaeus, 1758) have been collected on the Brazilian coast, but these may represent cases of unsuccessful introduction, as they have not been recorded since the original reports (Tavares and Mendonça Jr 2004).
The material from São Paulo was collected in 2007 (A. dimorphus) and 2009 (A. nitescens). Because of the small size and cryptic habits of these shrimps, they may have been overlooked for years after their arrival. There are two important commercial import and export harbors close to the collection sites, where the introduction may have taken place, Santos harbor $\left(23^{\circ} 58^{\prime} S\right)$, the most important Brazilian port, located very close to São Vicente estuary $\left(23^{\circ} 56^{\prime} \mathrm{S}\right)$, and São Sebastião harbor $\left(23^{\circ} 49^{\prime} \mathrm{S}\right)$, near Ubatuba $\left(23^{\circ} 30^{\prime} \mathrm{S}\right)$. If the introduction of $A$. nitescens succeeds, as is strongly suggested for A. dimorphus, the coast of São Paulo could act as a donor of larvae that could disperse by oceanic currents and intracoastal traffic.

Introduction of exotic species may have severe ecological consequences, among other possible damage. The effect of an established alien species on the recipient area could be direct, by displacement of indigenous species or predation on members of the invaded community, or indirect, by means of transmission of pathogens (Rodríguez and Suárez 2001; Tavares 2003). The Athanas species may compete for shelter and food with native alpheid shrimps inhabiting the same niche, such as some species of Synalpheus Spence Bate, 1888. The further impact of the introductions on native fauna will be difficult to evaluate because there is no basic knowledge about the biology and ecology of most alpheids. Members of Athanas are small, fragile, and non-burrowing organisms, with no snapping mechanism (typically used for communication, including aggressive behavior, in other alpheid genera). As such, their impact on native fauna and habitats is expected to be low (Pachelle et al. 2011).

Acknowledgments The authors are indebted to the Fundação de Amparo à Pesquisa do Estado de São Paulo (FAPESP) for providing financial support during field collections and visiting activities (Grants 2004/07309-8, 2008/53999-7, 2008/54991-0 to RCC, and 2009/54931-0, 2010/50188-8 to FLM) and to CNPq (Research Grant 479541/2007-08 and Research Scholarships PQ 306304/2008-2 to RCC, and PQ 302748/2010-5 to FLM). Thanks are extended to Marcos Tavares for the loan of MZUSP specimens. The authors are also indebted to three anonymous referees for the criticisms that greatly improved the manuscript. Dr. Janet Reid revised the English text.

\section{References}

Anker A (2001) Two new species of snapping shrimps from the IndoPacific, with remarks on colour patterns and sibling species in Alpheidae (Crustacea: Caridea). Raffles Bull Zool 49(1):57-72

Anker A (2011) Four new infaunal decapods crustaceans (Caridea: Alpheidae and Gebiidea; Axianassidae) from Lizard Island, Australia, one of them also occurring in Moorea, French Polynesia. Zootaxa 2734:1-22

Anker A, Ahyong ST (2007) Description of two species in the alpheid shrimp genus Athanas Leach, 1814, with remarks on A. amazone Holthuis, 1951 (Decapoda, Caridea). Zootaxa 1563:17-30 
Anker A, Jeng MS (2007) Establishment of a new genus for Arete borradailei Coutière, 1903 and Athanas verrucosus Banner \& Banner, 1960, with redefinitions of Arete Stimpson, 1860 and Athanas Leach, 1814 (Crustacea: Decapoda: Alpheidae). Zool Stud 46(4):454-472

Anker A, Komai T (2010) Description of a new species of Athanas Leach, 1814 (Crustacea: Decapoda: Alpheidae) from Madagascar and Japan. Zootaxa 2680:45-54

Anker A, Naderloo R, Marin I (2010) On a new species of the shrimp genus Athanas Leach, 1814 (Crustacea, Decapoda, Alpheidae) from Iran. Zootaxa 2372:53-60

Ateş AS, Katağan T, Kocataş A, Sezgin M (2006) Decapod crustaceans on the Gökçeada (Imbros) island continental shelf (north-eastern Aegean Sea). Mediterr Mar Sci 7(2):55-60

Banner DM, Banner AH (1973) The alpheid shrimp of Australia. Part I. The lower genera. Rec Aust Mus 28(15):291-382

Bartilotti C, Calado R, dos Santos A (2005) Correct diagnosis of early zoeal stages of Athanas nitescens (Leach, 1814) (Decapoda, Caridea, Alpheidae) using laboratory-raised larvae. J Plankton Res 27(11):1189-1194

Campos NH, Türkay M (1989) On a record of Charybdis hellerii from the Caribbean coast of Colombia (Crustacea: Decapoda: Portunidae). Senckenberg Marit 20(3/4):119-123

Chace FA Jr (1988) The Caridean Shrimps (Crustacea: Decapoda) of the Albatross Philippine Expedition, 1907-1910, Part 5: Family Alpheidae. Smithson Contrib Zool 466:1-99

Coutière H (1899) Les "Alpheidae", morphologie externe et interne, formes larvaires, bionomie. Ann Sci Nat Zool Series 8(9):1-560

Crosnier A (1971) Sur quelques Crustacés Décapodes ouest-africains nouveaux ou rarement signalés. Bull Mus Natl Hist Nat Series 3 Zool 9:569-595

d'Udekem d'Acoz C (1999) Inventaire et distribution des crustacés décapodes de l'Atlantique nord-oriental, de la Mediterranée et des eaux adjacentes au nord de $25^{\circ} \mathrm{N}$. Collection Patrimoines Naturels (M.N.H.N./S.P.N.) 40, pp 1-393

d'Udekem d'Acoz C, Wirtz P (2002) Observations on some interesting coastal Crustacea Decapoda from the Azores, with a key to the genus Eualus Thallwitz, 1892 in the Northeastern Atlantic and the Mediterranean. Arquipélago, Life and Marine Science 19A:67-84

Fernandes FC, Campos SHC, Plastina A (2009) Estrutura de prevenção e controle. In: Lopes $\mathrm{R}$ (ed) Informe sobre as espécies exóticas invasoras marinhas no Brasil. Ministério do Meio Ambiente/Secretaria de Biodiversidade e Florestas, Brasília, pp 397-423 (Série Biodiversidade, 33)

Galil BS (1992) Eritrean Decapods in the Levant. Biogeography in motion. Bull Inst Océanogr Monaco, no. Spécial 9:115-123

Galil B, Froglia C, Noël PY (2002) CIESM atlas of exotic species in the Mediterranean 2. Crustaceans. CIESM Publishers, Monaco

Gollasch S (2002) The importance of ship hull fouling as a vector of species introductions into the North Sea. Biofouling 18(2): 105-121

Gómez O, Martínez-Iglesias JC (1990) Reciente hallazgo de la especie indopacífica Charybdis hellerii (A. Milne-Edwards,1867) (Crustacea: Decapoda: Portunidae) en aguas cubanas. Caribb J Sci 26(1/2): $70-72$

Holthuis LB (1951) The caridean crustacea of Tropical West Africa. Atlantide Rep 2:7-187

Holthuis LB, Gottlieb E (1958) An annotated list of the decapod Crustacea of the Mediterranean coast of Israel, with an appendix listing the Decapoda of the Eastern Mediterranean. Bull Res Counc Israel 7B(1-2):1-126

Knowlton RE (1973) Larval development of the snapping shrimp Alpheus heterochaelis Say reared in the laboratory. J Nat Hist 7:273-306

Leach WE (1813-1814) Crustaceology. In: Brewsler D (ed) The Edinburgh Encyclopaedia 7:383-437

Ledoyer M (1968) Écologie de la faune vagile des biotopes méditerranéens accessible en scaphandre autonome (Région de Marseille principalement). IV. Synthèse de l'étude écologique. Recl Trav Stn Mar Endoume 44(60):125-295

Lemaitre R (1995) Charybdis hellerii (Milne Edwards, 1867), a nonindigenous portunid crab (Crustacea: Decapoda: Brachyura) discovered in the Indian River lagoon system of Florida. Proc Biol Soc Wash 108(4):643-648

Manoudis G, Antoniadou C, Dounas K, Chintiroglou CC (2005) Successional stages of experimental artificial reefs deployed in Vistonikos gulf (N. Aegean Sea, Greece): preliminary results. Belg J Zool 135(2):209-215

Mantelatto FL, Dias LL (1999) Extension of the known distribution of Charybdis hellerii (A. Milne-Edwards, 1867) (Decapoda, Portunidae) along the western tropical South Atlantic. Crustaceana 72(6):617-620

Mantelatto FL, Garcia RB (2001) Biological aspects of the nonindigenous portunid crab (Charybdis hellerii) in the western tropical South Atlantic. Bull Mar Sci 68(3):469-477

Ortmann A (1894) Crustaceen. In: Semon R (ed) Zoologische Forschungsreisen in Australien und dem Malayischen Archipel mit Unterstützung des Herrn Dr. Paul von Ritter ausgeführt in den Jahren 1891-93. Denksch Med-Naturw Ges Jena 8:3-80

Pachelle PPG, Mendes CB, Anker A (2011) The Indo-West Pacific alpheid shrimp Athanas dimorphus Ortmann, 1894: first record for Brazil and the Western Atlantic. Nauplius 19(1):89-96

Rodríguez G, Suárez H (2001) Anthropogenic dispersal of decapod crustaceans in aquatic environments. Interciencia 26(7):282-288

Tavares M (2003) Espécies exóticas aquáticas e saúde ambiental. O Mundo da Saúde 27(4):530-537

Tavares M (2011) Alien decapod crustaceans in the Southwestern Atlantic Ocean. In: Galil BS, Clark PF, Carlton JT (eds) In the wrong place-alien marine crustaceans: distribution, biology and impacts. Invading Nature-Springer Series in Invasion Ecol 6:251-268

Tavares M, Amouroux JM (2003) First record of the non-indigenous crab, Charybdis hellerii (A. Milne-Edwards, 1867) from French Guyana (Decapoda, Brachyura, Portunidae). Crustaceana 76(5):625-630

Tavares MD, Mendonça Jr JB (1996) Charybdis hellerii (A. Milne Edwards, 1867) (Brachyura: Portunidae), eight nonindigenous marine decapods recorded from Brazil. Crustac Res 25:151-157

Tavares MD, Mendonça Jr JB (2004) Introdução de Crustáceos Decápodes Exóticos no Brasil: Uma Roleta Ecológica. In: Silva J, Souza R (Orgs) Água de Lastro e Bioinvasão. Interciência, Rio de Janeiro, pp 59-76

Tlig-Zouari S, Rabaoui L, Cosentino A, Irathni I, Ghrairi H, Ben Hassine OK (2011) Macrofauna associated with an introduced oyster, Pinctada radiata: spatial scale implications of community differences. J Sea Res 65:161-169

Wirtz P (1997) Crustacean symbionts of the sea anemone Telmatactis cricoides at Madeira and the Canary Islands. J Zool 242(4):799-811 